\title{
Clearance rates of jellyfish and their potential predation impact on zooplankton and fish larvae in a neritic ecosystem (Limfjorden, Denmark)
}

\author{
Lars Johan Hansson ${ }^{1, *}$, Ole Moeslund ${ }^{2}$, Thomas Kiørboe ${ }^{1}$, Hans Ulrik Riisgård ${ }^{2}$ \\ ${ }^{1}$ Danish Institute for Fisheries Research, Kavalergården 6, 2920 Charlottenlund, Denmark \\ ${ }^{2}$ Marine Biological Research Centre (University of Southern Denmark) Hindsholmvej 11, 5300 Kerteminde, Denmark
}

\begin{abstract}
Clearance rates of the hydromedusae Sarsia tubulosa, Rathkea octopunctata and Bougainvillea superciliaris and the scyphomedusa Aurelia aurita were measured in the laboratory. Gut contents analyses of $A$. aurita were also collected in situ and subsequently used for estimation of clearance rate. The clearance rate of $A$. aurita varied widely with prey organisms. Large crustacean prey with low escape capabilities (Artemia salina nauplii and cirripede larvae) were cleared at high rates, whereas copepodites were cleared at lower rates, and clearance rates of small bivalve larvae and copepod nauplii were comparatively low. These data were used to assess the impact of jellyfish predation upon zooplankton and fish larvae in Limfjorden, Denmark. Repeated sampling of zooplankton, fish larvae and medusae was undertaken during the first half of 2003. Nine taxa of hydromedusae and 4 taxa of scyphomedusae were identified. Abundance estimates were combined with estimated clearance rates of individual medusae to calculate potential jellyfish-induced mortality on prey in Limfjorden. Copepoda was used as a model prey group to estimate the collective predation impact by all medusae. Medusa species with unknown clearance potential were given assumed clearance rate values, but the collective predation potential by these species was evaluated to be small. Hydromedusae dominated numerically and had their highest potential clearance impact in spring, but overall jellyfish clearance potential on copepods was low during this period. From May A. aurita was the most abundant jellyfish and the potential jellyfish predation impact became totally dominated by this scyphomedusa. Clearance potential was locally high on some prey, and predation by A. aurita probably controlled the abundance of cirripede larvae and fish larvae in Limfjorden. For these prey groups, half-life expectancy was less than $1 \mathrm{~d}$ at several locations.
\end{abstract}

KEY WORDS: Aurelia aurita $\cdot$ Sarsia $\cdot$ Rathkea $\cdot$ Barnacle $\cdot$ Hydromedusa $\cdot$ Scyphomedusa $\cdot$ Feeding

\section{INTRODUCTION}

Numerous experimental studies have shown that hydrozoan and scyphozoan jellyfish have the potential to consume considerable amounts of prey (Morand et al. 1987, de Lafontaine \& Leggett 1988, Båmstedt et al. 1994, Purcell \& Cowan Jr 1995, Duffy et al. 1997, Båmstedt et al. 2001). When jellyfish occur in high numbers, their collective prey-consumption rate can be so high that this predation directly or indirectly controls the population size of other zooplankton organisms (Huntley \& Hobson
1978, Feigenbaum \& Kelly 1984, Baird \& Ulanowicz 1989, Matsakis \& Conover 1991, Purcell 1992, Schneider \& Behrends 1994, Olesen 1995, Riisgård et al. 1995, Nielsen et al. 1997) including fish (Möller 1984, Øiestad 1985, Purcell \& Grover 1990). Intense predation by jellyfish on certain prey can cause a shift in the trophic structure of the pelagic community as a result of trophic cascading (Behrends \& Schneider 1995, Schneider \& Behrends 1998, Stibor et al. 2004). However, the effects of jellyfish predation upon ecosystem components are not always conspicuous but appear to vary (Fancett \& Jenkins 1988, Schnei- 
der 1989, Olsson et al. 1992, Purcell \& Nemazie 1992, Purcell et al. 1994, Brodeur et al. 2002).

It has been suggested that jellyfish predation might be an important factor shaping the pelagic ecosystem structure in Limfjorden. The waters of Limfjorden have been targeted as a fishing area since prehistoric times. However, between 1981 and 1996 the landings of edible fish such as eel, plaice and cod were severely reduced (Dolmer \& Frandsen 2002), and one of the locally raised hypotheses was that the reduced landings might have been due to jellyfish. Interest in the possible effects of jellyfish predation on fish eggs and fish larvae motivated the local county authorities to finance a survey of fish and jellyfish in Limfjorden. The survey was conducted in spring months from 1996 to 1999 by a consulting company (Bio/consult 2001). In total, 10 taxa of medusae were identified, and a high spatial and temporal variation in jellyfish density was found (Bio/consult 2001). A weak, but significant, negative correlation between jellyfish biomass and concentration of fish eggs in spring was discovered (Bio/consult 2001). However, the magnitude of jellyfish-induced mortality in Limfjorden remained to be clarified.

In the present study we investigate whether jellyfish predation can control the abundances of zooplankton in a neritic ecosystem as exemplified by Limfjorden. Clearance rates of 4 common neritic medusae (Aurelia aurita, Sarsia tubulosa, Rathkea octopunctata, and Bougainvillia superciliaris) were quantified, and the potential predation impact exerted by jellyfish on zooplankton and fish larvae in Limfjorden during spring and summer 2003 was assessed. Potential jellyfishinduced mortalities were estimated from jellyfish clearance rates and abundances, and the relative predation potential of hydromedusae and scyphomedusae was evaluated.

\section{MATERIALS AND METHODS}

Study area. Limfjorden is a $1500 \mathrm{~km}^{2}$ water system that crosses northern Jutland, Denmark and connects the North Sea in the west with the Kattegat in the east (Fig. 1). It consists of several basins that are partially separated by shallow waters or narrow sounds. The average depth is $4.3 \mathrm{~m}$, and the maximum depth is $28 \mathrm{~m}$. An eastward net residual current brings higher-salinity (usually >30) North Sea water into the area. Limfjorden also receives a high influx of freshwater from the surrounding, mainly agricultural, land area, which results in a salinity gradient from west to east and brackish water conditions in the inner southeastern bays (ca. 20 to 25). The salinity is sometimes slightly higher at the bottom than at the surface (Jørgensen 1980).

Field investigations. Plankton was sampled during daytime at 12 locations in the western and central part of Limfjorden during 5 cruises in 2003 (24 to 27 February, 8 to 11 April, 20 to 24 May, 1 to 4 July, and 26 to 27 August) (Fig. 1). During the first 4 cruises zooplankton (30 or $50 \mu \mathrm{m}$ sieved microzooplankton and mesozooplankton), fish larvae and jellyfish were sampled to determine sizes and densities, but the last cruise was aimed only at size and density of large scyphozoan jellyfish at Locations B, H, I, J, L, M, and N.

Medusae were collected with a $500 \mu \mathrm{m}$ Bongo net $\left(0.29 \mathrm{~m}^{2}\right.$ mouth area), and sampling for large medusae (>15 mm diameter) was complemented with a $2 \mathrm{~mm}$ plankton net $\left(1.77 \mathrm{~m}^{2}\right.$ mouth area). Both nets were equipped with large, closed cod end buckets to prevent damage of the jellyfish. Oblique hauls throughout the water column were made for abundance estimates. An echo sounder mounted on
Fig. 1. Map showing location of Limfjorden with detailed bathygraphic map of sampled locations $(\mathrm{A}-\mathrm{N})$ in Limfjorden, northern Denmark. A: Thyborøn Kanal $\left(56^{\circ} 42^{\prime}-8^{\circ} 14^{\prime}\right)$; B: Nissum Bredning $\left(56^{\circ} 36^{\prime}-8^{\circ} 27^{\prime}\right)$; C: Venø Bugt $\left(56^{\circ} 34^{\prime}-8^{\circ} 42^{\prime}\right)$; D: Kås Bredning $\left(56^{\circ} 40^{\prime}-8^{\circ} 44^{\prime}\right)$; E: Sallingsund $\left(56^{\circ} 43^{\prime}-8^{\circ} 49^{\prime}\right)$; F: Nykøbing $\left(56^{\circ} 49^{\prime}-8^{\circ} 56^{\prime}\right)$; G: Livø $\left(56^{\circ} 51^{\prime}-9^{\circ} 08^{\prime}\right)$; H: Visby Bredning $\left(56^{\circ} 47^{\prime} 50^{\prime \prime}-8^{\circ} 31^{\prime}\right)$; I: Thisted Bredning $\left(56^{\circ} 55^{\prime}-8^{\circ} 47^{\prime}\right)$; J: Løgstør Bredning $\left(56^{\circ} 59^{\prime}-9^{\circ} 03^{\prime}\right)$; K: Løgstør Kanal $\left(56^{\circ} 59^{\prime}-9^{\circ} 16^{\prime} 50^{\prime \prime}\right)$; L: Risgårde Bredning $\left(56^{\circ} 45^{\prime}-9^{\circ} 08^{\prime}\right) ;$ M: Skive Fjord $\left(56^{\circ} 39^{\prime}-9^{\circ} 07^{\prime}\right)$; N: Lovns Bredning $\left(56^{\circ} 38^{\prime}-9^{\circ} 12^{\prime}\right)$. Depth increases with darkness of gray scale 
the net provided continuous information about the sampling depth, so that the water column could be homogenously sampled from near the seabed to the surface. Plankton net entrances were fitted with General Oceanics flow meters to quantify the time-integrated velocity of water entering each net. The volume of water sampled by a net was calculated from entrance area times the active distance that the net travelled through the water, using distance information collected from the flow meter. Repeated short (typically 2 to $5 \mathrm{~min}$ ) tows at 1.5 knots were made at each location. Samples from the Bongo net were preserved in formalin (all formalin used as preservative in this study was $4 \%$ buffered with Borax), and the jellyfish were later counted and measured (bell height or bell diameter) in the laboratory. Sizes of some medusae were measured before and after preservation to obtain data that were later used to adjust size measurements of preserved medusae for any shrinkage caused by the preservative. Samples of large scyphozoan medusae, collected with the big net, were counted within $1 \mathrm{~h}$ after collection. Interrhopalia diameters of living large medusae were measured by placing them with the exumbrella downwards over a millimeter scale.

Abundances of fish larvae were estimated from 2.5 knot hauls with a $500 \mu \mathrm{m}$ Bongo net towed obliquely between near seabed and surface. Samples were preserved in formalin and later analyzed under a dissecting microscope. Fish larvae were identified and counted and their lengths measured.

Zooplankton throughout the water column was collected with an electric plankton pump fitted with a General Oceanics flow meter and a 30 or $50 \mu \mathrm{m}$ collector net. The latter was used when phytoplankton clogged the former. Samples were preserved in formalin, and organisms were identified to various systematic levels and counted.

Clearance rate estimates. The scyphomedusa Aurelia aurita or the hydromedusae Rathkea octopunctata and Sarsia tubulosa are dominant jellyfish species in several neritic ecosystems (van der Veer 1985, Matsakis \& Conover 1991, Kopacz 1994), including Limfjorden, and were therefore selected for clearance measurements. A single measurement of the clearance rate of Bougainvillia superciliaris was also made. Jellyfish clearance rates were measured in laboratory experiments as volume of water cleared of prey organisms per unit time. Hydromedusae used in the experiments were collected in Limfjorden, and sizes of the medusae used were representative for medusae in the area. Experimental con- ditions are listed in Table 1. Temperatures were selected to cover a wide spectrum of expected in situ water temperatures. A known number of prey organisms were initially added to a number of experimental tanks with a defined volume $(V)$ of filtered seawater containing one or several jellyfish.

For Aurelia aurita and Rathkea octopunctata the exponential reduction in number of prey organisms over time was followed by repeated subsampling of the incubation water throughout the incubations. Prey organisms in the subsamples from the experimental tanks were counted under a dissecting microscope. The individual daily clearance rate $\left(F_{i}\right)$ of medusa species $i$ was determined from the exponential reduction in prey organism concentration using the formula:

$$
F_{i}=-\frac{a V}{n}
$$

where $a=$ slope of the fitted regression line in a plot of ln $C_{t}$ versus time, $n=$ number of jellyfish in the experimental tank, and $C_{t}$ is prey concentration at time $t$.

For Sarsia tubulosa and Bougainvillia superciliaris, only start $\left(C_{0}\right)$ and final $\left(C_{t}\right)$ prey concentrations were registered, and the individual clearance rate was calculated as:

$$
F_{i}=\left(\frac{V}{n t}\right) \times \ln \left(\frac{C_{0}}{C_{t}}\right)
$$

All clearance experiments were adjusted for any changes in prey numbers in simultaneous controls without medusae.

Clearance rates of scyphozoan jellyfish vary with medusa size (Olesen 1995). To estimate the predatory impact of the dominant scyphomedusa in Limfjorden, Aurelia aurita, $F_{i}$ was estimated from number of prey in the guts $(G)$, prey plankton concentration in the ambient water $(C)$ and prey digestion times $(E)$. At several locations in April, May and July, A. aurita medusae were collected with a dip net or with a verti-

Table 1. Experimental conditions during clearance rate experiments. Prey types were Acartia tonsa nauplii (At.n), A. tonsa adults (At.ad) and Artemia salina nauplii (Art). Medusa sizes were measured as bell height for all jellyfish except Aurelia aurita, where diameter was measured

\begin{tabular}{|lcccc|}
\hline Predator & $\begin{array}{c}\text { Size } \\
(\mathrm{mm})\end{array}$ & Prey & $\begin{array}{c}\text { Temperature } \\
\left({ }^{\circ} \mathrm{C}\right)\end{array}$ & $\begin{array}{c}\text { Incubation } \\
\text { volume }(\mathrm{l})\end{array}$ \\
\hline Aurelia aurita & $5.1-6.2$ & At.n & 15 & $0.5-0.6$ \\
& $36-215$ & Art & $12.5-17$ & $75-536$ \\
Rathkea octopunctata & $1.2-2.2$ & At.n & 15 & 0.6 \\
& & At.ad & 4 & 0.6 \\
Sarsia tubulosa & 5.1 & Art & $8-14.5$ & $0.1-0.4$ \\
Bougainvillia superciliaris & $3-10$ & At.n \& At.ad & 11 & 0.6 \\
& & & 13 & 0.6 \\
\hline
\end{tabular}


cally hauled $350 \mu \mathrm{m}$ plankton net and immediately preserved in formalin. Prey contents in the gastric pouches of the medusae were later analyzed. Prey ingestion rate $(I)$ was calculated as:

$$
I=\frac{G}{E}
$$

and $F_{i}$ was calculated as:

$$
F_{i}=\frac{I}{C}
$$

Different studies have found varying digestion times in jellyfish and averaged over a number of studies Martinussen \& Båmstedt (2001) found a small reduction in digestion time with increasing temperature. Therefore, in the present work the estimated digestion times were adjusted for temperature. According to CTD data collected on each of the sampling cruises in Limfjorden, temperature was homogenous throughout the water column, and at any location it varied less than $1^{\circ} \mathrm{C}$ between water surface and seabed. Average temperatures in Limfjorden during the 5 sampling cruises were $0.5,5,12,17$ and $18^{\circ} \mathrm{C}$. To find the relation between temperature and digestion time in Aurelia aurita, values of digestion time reported in the literature were plotted against temperature (Matsakis \& Conover 1991, Sullivan et al. 1994, Martinussen \& Båmstedt 1999, 2001, Båmstedt \& Martinussen 2000, Dawson \& Martin 2001, Ishii \& Tanaka 2001) (Fig. 2).

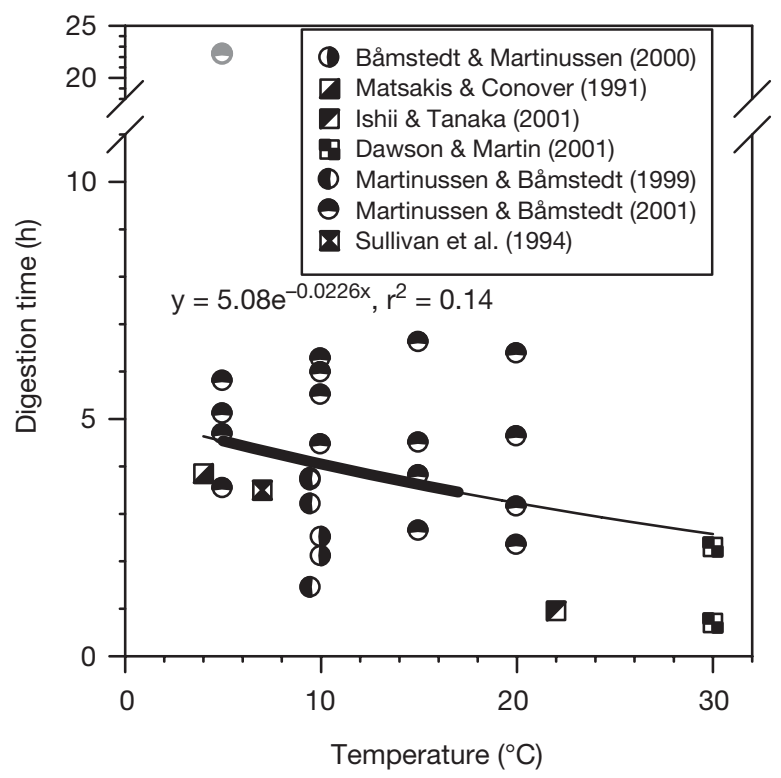

Fig. 2. Aurelia aurita. Literature data on prey digestion time at different temperatures. Gray data point was not included in regression. Bold part of regression line = range of temperatures in Limfjorden when medusae for gut content analysis were collected
Digestion times for A. aurita were adjusted according to the obtained relation. However, because the data for this relation were based almost exclusively on digestion times of copepodites (including adult copepods), corrections for other prey organisms were made. Larson (1991) found for Stomolophus meleagris that digestion time varied among prey types, and factors from that study were applied in the present work. Thus adjusted digestion times were obtained by multiplying the digestion time of copepods with the following factors: copepod nauplii 0.67 ; cirripeda, gastropoda, cladocera 1.33; bivalvia 2.67 .

Predation impact. For each sampled location, jellyfishinduced prey mortality rate $\left(\mu, \mathrm{d}^{-1}\right)$ was calculated as:

$$
\mu=\sum_{i}^{J} F_{i} D_{i}
$$

where $D_{i}$ is the density of medusae of species $i$ and $J$ is the number of jellyfish species at the location. For jellyfish species where $F_{i}$ depends on jellyfish size, average size for species $i$ at the location was used in the calculations. However, clearance rate is known only for a small number of jellyfish-prey combinations, and copepods were selected as model prey to assess the possible contribution of all medusae to the predation impact. Jellyfish species of unknown $F_{i}$ were attributed with a hypothetical $F_{i}$ based on either literature data for intrageneric species or on morphological resemblance with species where clearance rate has been measured. Thus, the same $F_{i}$-values as for Rathkea octopunctata were applied to medusae of Aglantha digitale. Because Hybocodon prolifer only has a single fishing tentacle compared to 4 tentacles of Sarsia sp., a clearance rate 0.25 times that found for Sarsia sp. was applied to $H$. prolifer. Data on clearance rate of Obelia geniculata (Fulton \& Wear 1985) were applied to Obelia sp. from Limfjorden. For oblate medusae that can be expected to forage in a cruising mode (Tiaropsis multicirrata, Phialidium hemisphaericum, Eutonina indicans, Cyanea capillata) the same relations between $F_{i}$ and size as for $A$. aurita were applied. These values are not very accurate, and a sensitivity analysis was thus conducted by calculating how these species' contribution to the overall clearance potential on copepods varied when the assumed clearance values were modified upwards and downwards by a factor of 10 .

Theoretical mean half-life time $\left(t_{1 / 2}\right)$ (e.g. Riisgård et al. 1995) of a prey organism before being captured by a jellyfish was calculated from mortality rate $\left(\mu, \mathrm{d}^{-1}\right)$ as:

$$
t_{1 / 2}=\frac{\ln 2}{\mu}
$$

Because clearance potential is unknown for most jellyfish-prey combinations, it is presently not possible to calculate $\mu$ or $t_{1 / 2}$ for most prey species. However, 

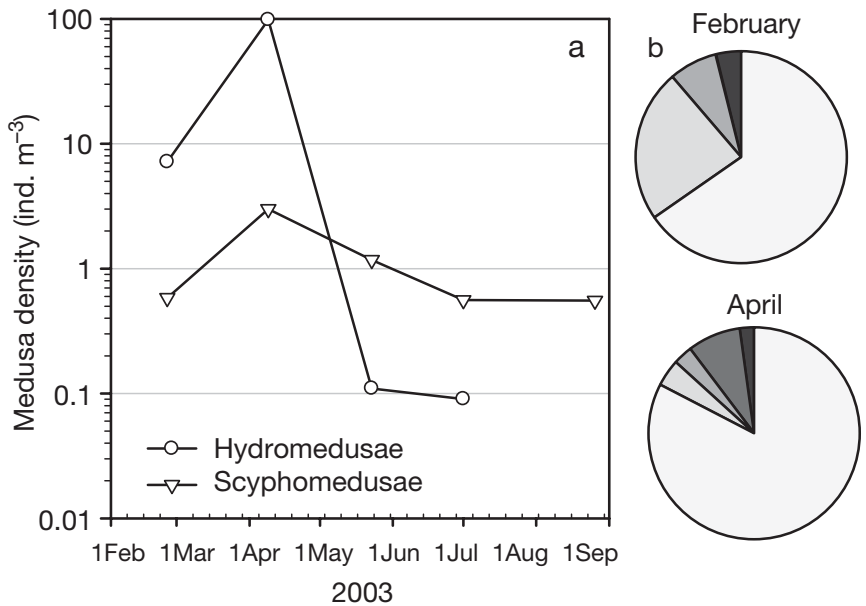

Fig. 3. Hydromedusae and scyphomedusae in Limfjorden, averaged over all sampled locations. (A) Density (ind. $\mathrm{m}^{-3}$ ) over time. Minor tick marks = week intervals. (B) Relative frequency of different medusae. The 5 gray shadings represent, in order from light to dark, Rathkea octopunctata, Sarsia sp., Aurelia aurita, Obelia sp., and other medusae. In February the fraction of Obelia sp. was so small that it could not be distinguished in the graph
Hydromedusae were the numerically dominant jellyfish in spring (Fig. 3a). This class of jellyfish displayed large fluctuations in abundance over time. During 6 wk from February to April 2003, the density of hydromedusae increased by more than 1 order of magnitude to a maximum average abundance of 98 ind. $\mathrm{m}^{-3}$ with local densities as high as 368 ind. $\mathrm{m}^{-3}$. Then, between early April and mid May the hydromedusan population densities dropped from 98 to 0.11 ind. $\mathrm{m}^{-3}$. The overall average abundance of scyphomedusae in Limfjorden was high and even over time. Over 6 mo, this group, which consisted almost exclusively of $A$. aurita, on average varied between 0.6 and 3 ind. $\mathrm{m}^{-3}$.

The species composition of jellyfish varied over time. Numerically dominant groups were Rathkea octopunctata and Sarsia sp. in February R. octopunctata and Obelia sp. in April (Fig. 3b) and Aurelia aurita in both May and June. Only a few specimens of Obelia sp. and Tiaropsis multicirrata were collected in February, but in April these jellyfish species occurred in most locations.

Variability in the abundance and species composition of the jellyfish community was detected over rela- prey-specific clearance rates of $A$. aurita for different prey species were used to illustrate how differences in clearance efficiency affects mortality rate. $\mu$ and $t_{1 / 2}$ were calculated for this dominant scyphozoan jellyfish alone to yield a conservative estimate of jellyfish predation on prey captured with the same efficiency as Artemia salina and cirripede nauplii.

\section{RESULTS}

\section{Plankton in Limfjorden}

\section{Jellyfish}

A number of taxa of jellyfish were observed in the studied area. Nine hydromedusae (Obelia sp., Rathkea octopunctata, Sarsia sp., Hybocodon prolifer, Bougainvillia sp., Tiaropsis multicirrata, Phialidium hemisphaericum, Eutonina indicans, and Aglantha digitale) and 4 scyphomedusae (Aurelia aurita, Cyanea lamarckii, Cyanea capillata, and Chrysaora hysoscella) were identified to species or genus, but other gelatinous groups were also observed (ctenophores and appendicularians).

Fig. 4. Maps showing abundance of scyphomedusae at 5 sampling times in Limfjorden

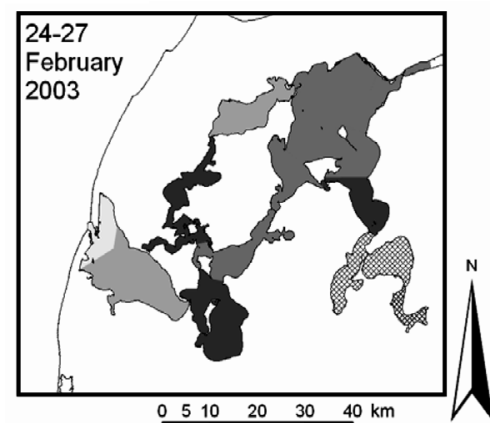

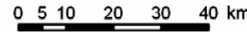
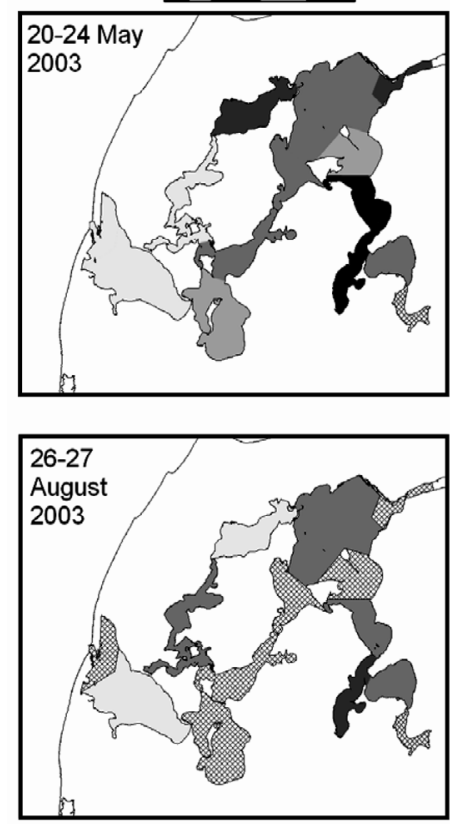
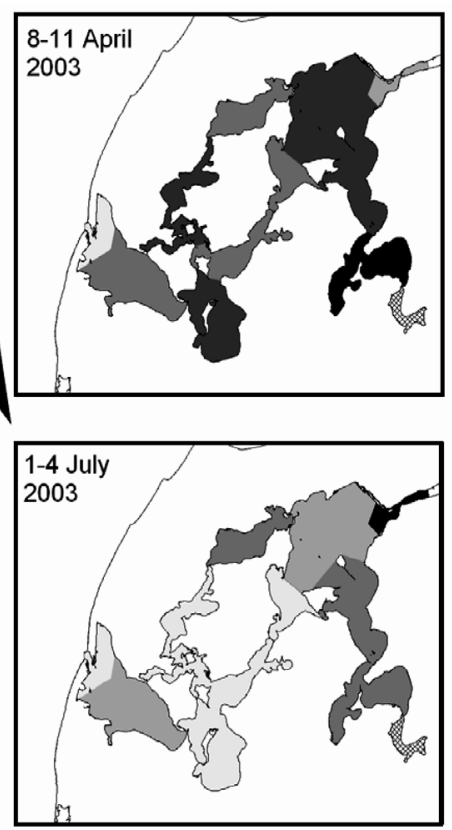

Scyphomedusae

Abundance (ind. $1000 \mathrm{~m}^{-3}$ ) 0-50 50-250

250-1000

1000-3000

$3000-12000$

no data 


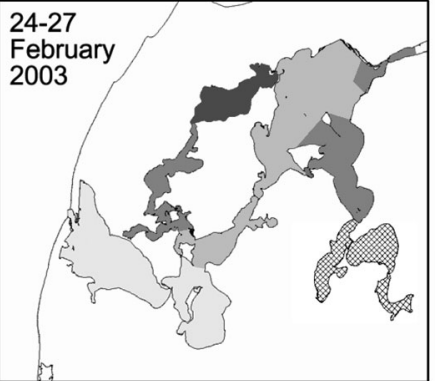

Hydromedusae

Abundance (ind. $\mathrm{m}^{-3}$ )

0-1.5

$1.5-7$

7-25

$25-100$

$100-400$

no data

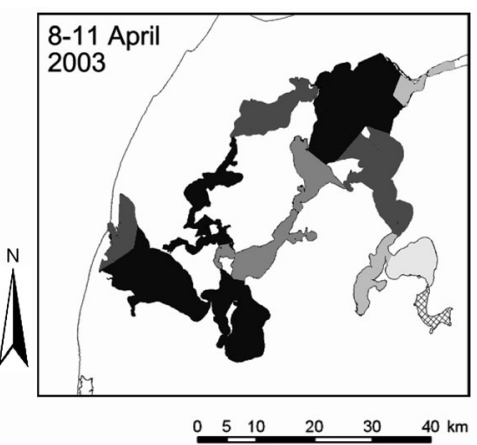

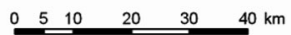

entrances to the study area could be noted in the composition of medusae. Thus, Aglantha digitale, Phialidium hemisphaericum, Eutonina indicans, Cyanea lamarckii and Chrysaora hysoscella were only observed in either the 2 most westerly locations (A, B) or in the canal entering the northeastern part of the study area $(\mathrm{K})$. Also Locations $\mathrm{M}$ and $\mathrm{N}$ differ from the central locations of Limfjorden because of their extraordinarily high abundance of Aurelia aurita and absence of Hybocodon prolifer.

\section{Zooplankton}

Fig. 5. Maps showing abundance of hydromedusae at 2 sampling times in Limfjorden tively small spatial scales (Figs. $4 \& 5$ ). The abundance of scyphomedusae was generally highest in the eastern parts of the investigated area, and it was always lowest at the western entrance to the fjord, indicating that abundance in Limfjorden is elevated compared to the North Sea, with which it is connected through Thyborøn Kanal. No consistent pattern was detetcted for the abundance of hydromedusae. In February these were least abundant in the western parts of Limfjorden, and in April, in the shallow southeastern basins. After April, the abundance of hydromedusae was less than 1.5 ind. $\mathrm{m}^{-3}$ at all sites.

The number of jellyfish species at each location was relatively similar throughout Limfjorden in spring, with a slightly higher number in April than in February. The highest recorded jellyfish diversity was found at Location A (Thyborøn Kanal) in April, where 10 types of jellyfish were identified from a $27 \mathrm{~m}^{3}$ plankton tow. Possible influence from the western and eastern

Table 2. Numerically dominating zooplankton (ind. $\mathrm{l}^{-1}$ ) and fish larvae (ind. $1000 \mathrm{~m}^{-3}$ ) averaged over all samples in Limfjorden from February to July 2003

\begin{tabular}{|lrrrc|}
\hline & Feb & Apr & May & July \\
\hline Zooplankton & & & & \\
Cirripede nauplii & 5.8 & & & \\
Centropages hamatus (nauplii) & 1.2 & 14.2 & 30.4 & \\
Rotifera & & 5.6 & & \\
Bivalve veliger larvae & & & 286 & 181 \\
Acartia spp. (nauplii) & & & & 13.6 \\
Fish larvae & 15.9 & & & \\
Myxocephalus scorpius & 1.3 & 32.5 & & \\
Pholis gunellus & & 36.9 & 229 & \\
Clupea harengus & & & 643 & 5191 \\
Gobiidae spp. & & & & 242 \\
Sprattus sprattus & & & & \\
\hline
\end{tabular}

The zooplankton community was dom-
inated numerically by cirripede nauplii in February, copepod nauplii of primarily Centropages hamatus in April and bivalve veligers in May and July (Table 2). C. hamatus was the most abundant adult copepod species in February to May. In July both Acartia clausi and A. discaudata were found in higher densities than $C$. hamatus.

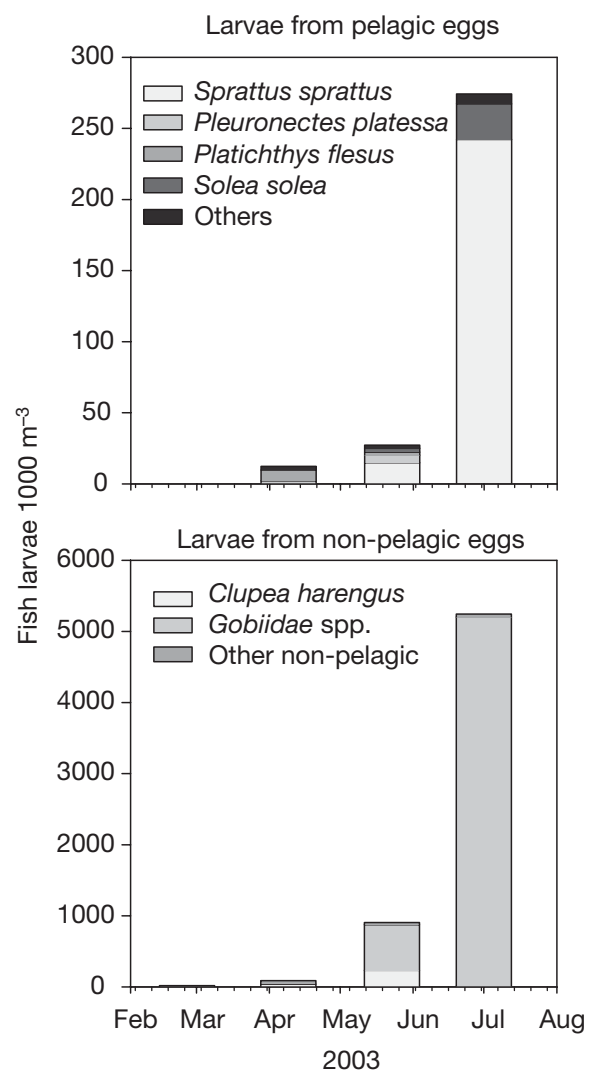

Fig. 6. Average abundance of fish larvae of species developed from pelagic and non-pelagic eggs. Note: scales of upper and lower panels are different 


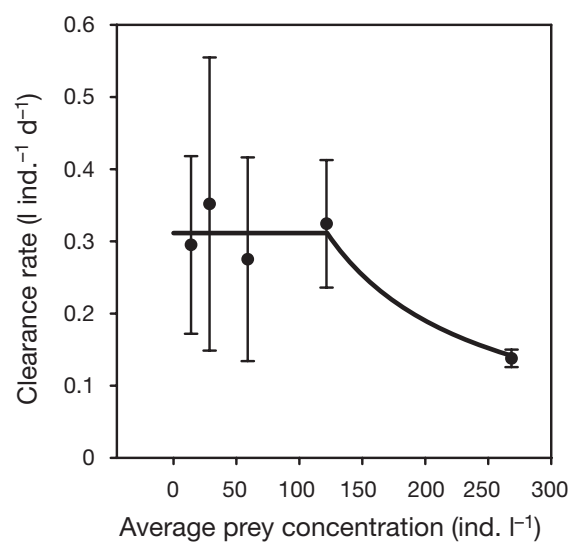

Fig. 7. Sarsia tubulosa. Clearance rate of medusae (average bell height $=5.1 \mathrm{~mm}$ ) feeding on adult Acartia tonsa at $11^{\circ} \mathrm{C}$. Error bars $=$ standard deviation. $\mathrm{n}=3$ to 8 . Fitted line assumes a constant clearance rate at the 4 lowest prey concentrations $\left(0.3 \mathrm{l}_{\mathrm{ind}} \mathrm{.}^{-1} \mathrm{~d}^{-1}\right)$ and saturated food uptake at higher concentrations. Maximum observed ingestion rate was thus 0.31 ind.$^{-1} \mathrm{~d}^{-1}$ multiplied by 115 prey $\mathrm{l}^{-1}=34$ prey ind. ${ }^{-1} \mathrm{~d}^{-1}$. The line fit to the right of 115 prey $\mathrm{l}^{-1}$ could be calculated as 34 prey ind. ${ }^{-1} \mathrm{~d}^{-1}$ divided by prey concentration (prey $\mathrm{l}^{-1}$ )

\section{Fish larvae}

Some larvae of fish species of commercial interest were found only at the 2 most westerly locations, but never in the more central parts of the area. Larvae from species that were found only in association with the western fjord entrance, but never retrieved in samples from the inner parts of Limfjorden, were pollack (Pollachius pollachius), dab (Limanda limanda), plaice (Pleuronectes platessa) and common sole (Solea solea). Larvae of commercially important fish that were observed in samples from the central fjord were sprat (Sprattus sprattus) May to July; herring (Clupea harengus) April to July; cod (Gadus morhua) and coalfish (Pollachius virens) April; flounder (Platichthys flesus) and sandeels (Ammodytes sp. and Hyperoplus sp.) April to May.

The average abundance of larvae of fish species that reproduce with pelagic eggs (e.g. sprat, dab, plaice, flounder, common sole, pollack, cod, coalfish, dragonet Callionymus sp., and four-bearded rockling Rhinonemus cimbrius) was at each sampling occasion more than one order of magnitude lower than that of larvae of fish with benthic eggs (e.g. herring, gunnel Pholis gunnellus, gobies gobiidae, short-spined sea scorpion Myxocephalus scorpius, and sand eels) and brooding fish (pipefish sygnathidae) (Fig. 6).

\section{Clearance rates of jellyfish}

The clearance rate of Sarsia tubulosa averaged $0.3 \mathrm{lind}^{-1} \mathrm{~d}^{-1}$ at copepod concentrations of up to
122 ind. $\mathrm{l}^{-1}$. At 269 prey $\mathrm{l}^{-1}$ the clearance rate was lower, possibly as an effect of prey saturation (Fig. 7). Bougainvillia superciliaris cleared the nauplius stage Acartia tonsa at a rate of $0.141 \mathrm{ind} .^{-1} \mathrm{~d}^{-1}$ and the adult stage $A$. tonsa at $0.171 \mathrm{ind}^{-1} \mathrm{~d}^{-1}$.

The clearance rate of Rathkea octopunctata depended on prey type, prey concentration and temperature (Fig. 8). Thus, the clearance rate on Artemia nauplii was higher than on Acartia tonsa nauplii, and the clearance rate on Artemia nauplii increased with temperature. At $4^{\circ} \mathrm{C} R$. octopunctata cleared $A$. tonsa copepods at a rate of 0.061 ind..$^{-1} \mathrm{~d}^{-1}$.

Aurelia aurita clearance rates, as estimated from laboratory experiments and gut content analyses, were a function of medusa size and prey type (Fig. 9). The clearance rate scaled approximately with bell diameter squared, as expected if the contact surface of a capture organ alone determined clearance rate. This was best documented for the largest prey types (Fig. 9a), but the same relationship was applied to the scattered data of the small prey types (Fig. 9b).

\section{Jellyfish predation impact}

Hydromedusae were the major contributors to the total jellyfish predation impact on copepods in February and early April (Fig. 10). During this time the most important hydromedusan predators at all sampled locations were Sarsia sp. and Rathkea octopunctata. Together they contributed approximately $90 \%$ of jellyfish predation on copepodites in both February and April. After early April, predation by jellyfish was totally dominated by scyphomedusae, primarily Aurelia aurita.

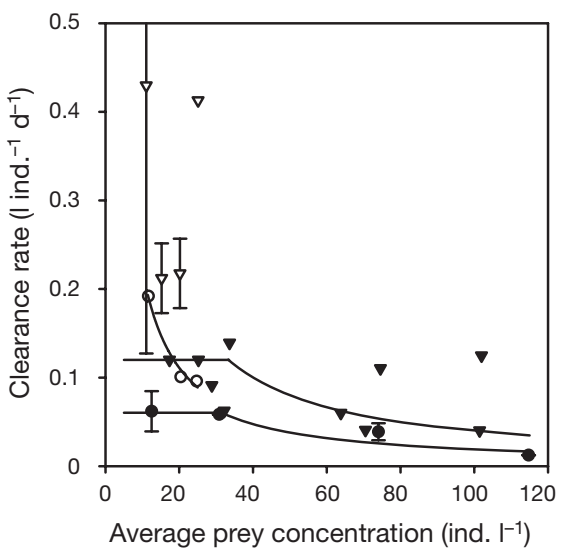

Fig. 8. Rathkea octopunctata. Clearance rate of medusae (average bell height $=1.2$ to $2.2 \mathrm{~mm}$ ) feeding on adult Acartia tonsa at $4^{\circ} \mathrm{C}(\bullet)$, nauplius stage $A$. tonsa at $15^{\circ} \mathrm{C}(\mathrm{O})$ or Artemia sp. nauplii at $8-10^{\circ} \mathrm{C}(\boldsymbol{\nabla})$ and $14.5^{\circ} \mathrm{C}(\nabla)$. Error bars = standard deviation. Lines fitted from ingestion data, as in Fig. 7, for all data except $\nabla$ 

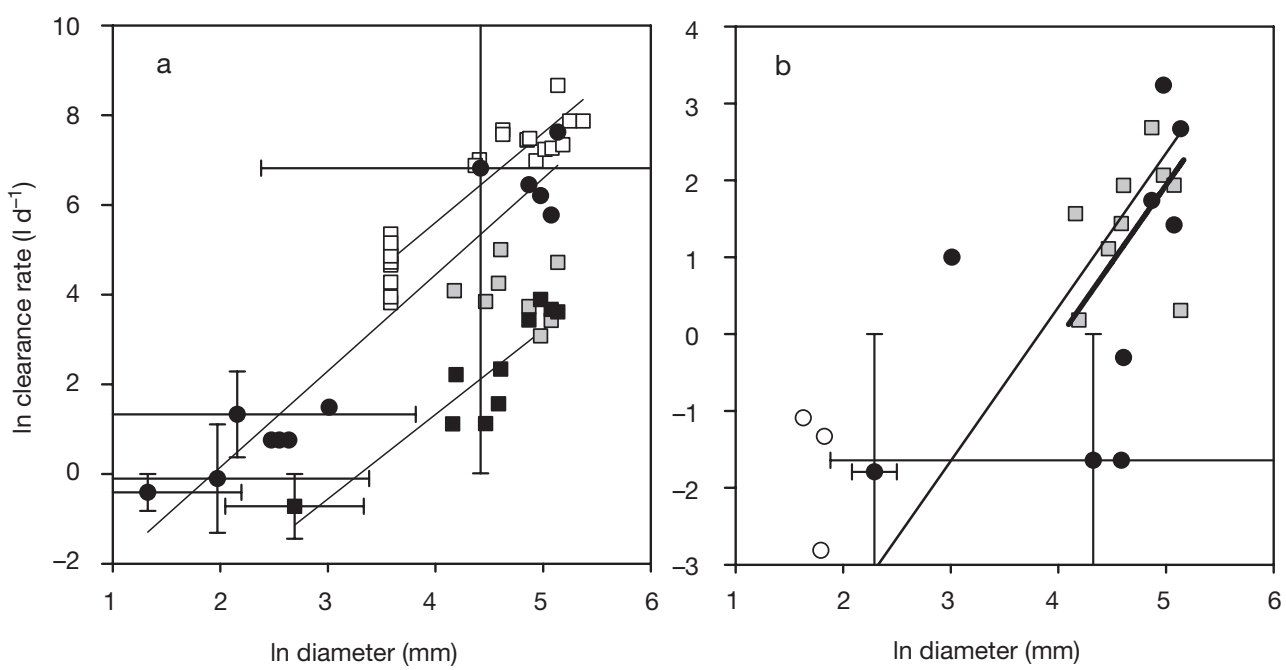

Fig. 9. Aurelia aurita. (A) Clearance rate estimated from laboratory feeding experiments (open squares: Artemia sp.) and from gut contents of field collected medusae ( $\bullet$ : cirripede larvae; $\square$ : cladocera; $\mathbf{\square}$ : copepodites including adult copepods). Size-dependent clearance rates $\left(1\right.$ ind. $\left.^{-1} \mathrm{~d}^{-1}\right)$ were $0.0923 D^{2.00}, \mathrm{r}^{2}=0.88, \mathrm{p}<0.001$ (Artemia nauplii); $0.0159 D^{2.15}, \mathrm{r}^{2}=0.93, \mathrm{p}<0.001$ (cirripede larvae); and $2.025 \times 10^{-3} D^{1.88}, \mathrm{r}^{2}=0.82, \mathrm{p}<0.001$ (copepodites), where $D$ is medusa diameter in mm. (B) Clearance rate estimated from laboratory feeding experiments (o: copepod nauplii) and from gut contents of field collected medusae ( $\bullet$ : copepod nauplii; $\square$ : bivalve larvae). Regression lines fitted with exponent set to 2 were $4.77 \times 10^{-4} D^{2}, \mathrm{r}^{2}=0.46, \mathrm{p}=0.002$ (thin regression line: copepod nauplii), and $3.15 \times 10^{-4} D^{2}, \mathrm{r}^{2}=0.49, \mathrm{p}<0.001$ (bold regression line: bivalves)

Potential predation was not homogenous throughout the investigated area but was highest in the eastern and southeastern parts of Limfjorden (Table 3, Fig. 11). In February and early April jellyfish-induced mortality rates were low and zooplankton half-life times $\left(t_{1 / 2}\right)$ were consequently long (Tables $3 \& 4$ ). It is evident

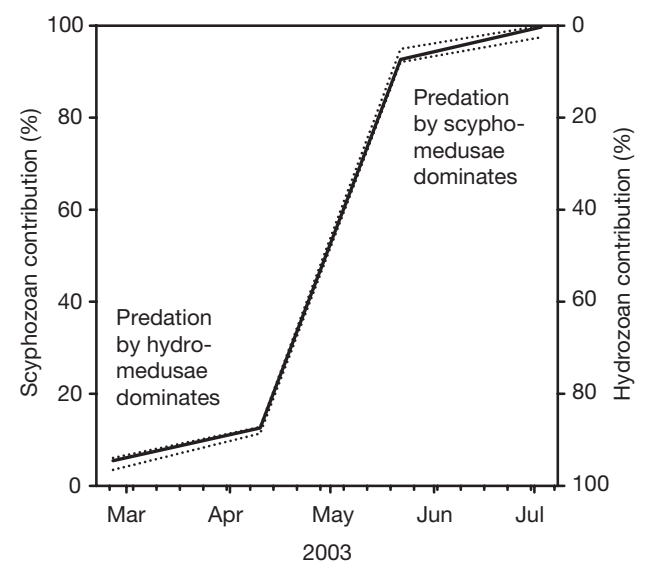

Fig. 10. Scyphozoan and hydrozoan contribution to total jellyfish predation impact on copepodite prey averaged over all sampled locations in Limfjorden. Solid line is based on measured clearance rates of Aurelia aurita, Sarsia tubulosa, Rathkea octopunctata, and Bougainvillea superciliaris as well as assumed clearance rate values for other jellyfish species. Dotted lines are based on the same data except for the assumed clearance rate data, which have been increased or decreased by a factor of 10 to illustrate the sensitivity to these assumed values that any zooplankter Aurelia aurita captured as efficiently as Artemia salina would face a very short halflife expectancy in July to August as a result of predation by this predator alone (Table 4 ). After May $t_{1 / 2}$ of $<2 \mathrm{~d}$ are expected for such prey at most locations in eastern Limfjorden.

\section{DISCUSSION}

\section{Comparison of data with previous observations}

Species composition and abundance of hydromedusae in Limfjorden appear to be rather typical for North Atlantic neritic ecosystems, and the findings from this study may thus provide insight for other areas. Although Limfjorden is an enclosed shallow area of moderate size, the spring species diversity of jellyfish was relatively high with 9 hydromedusae identified from a half year sampling in 2003 and $\geq 8$ species of hydromedusae identified in spring 1996 to 1999 by Bio/consult (2001). During 7 yr of monthly measurements in the North Sea, Nicholas \& Frid (1999) found 15 taxa of hydromedusae. Tiaropsis multicirrata was the only medusa found in Limfjorden that Nicholas \& Frid (1999) never observed on the northeast coast of England.

Matsakis \& Conover (1991) investigated the spring development of the medusa community in Bedford Basin, Canada. Considering the high intersite abundance variation that some jellyfish species display, the 
situation in Bedford Basin in May 1988 was surprisingly similar to the April situation in Limfjorden regarding dominant hydromedusae and scyphomedusae: 95 Rathkea octopunctata $\mathrm{m}^{-3}$ (84 ind. $\mathrm{m}^{-3}$ in Limfjorden) and approximately 0.5 Aurelia aurita $\mathrm{m}^{-3}$ (3 ind. $\mathrm{m}^{-3}$ in Limfjorden).

Rathkea octopunctata and Sarsia tubulosa were the dominant medusae in the Wadden Sea area in 1991 and 1992 (Kopacz 1994). Median abundance ranged between 9.5 and $44 R$. octopunctata $\mathrm{m}^{-3}$ and between 1.0 and $12 \mathrm{~S}$. tubulosa $\mathrm{m}^{-3}$. Further south, in the western part of the Dutch Wadden Sea, van der Veer (1985) observed peak densities of 5.5 and 2.5 S. tubulosa $\mathrm{m}^{-3}$ in 1981 and 1982 respectively. Average Limfjorden densities of Sarsia were 1.8 (February) and 4.2 (April) medusae $\mathrm{m}^{-3}$, which appears to be similar to the Wadden Sea area.

Previous sampling in Limfjorden was conducted by Blanner (1982) and Bio/consult (2001). Blanner (1982) sampled zooplankton 11 times over 1 yr (November 1973-1974) at 2 locations in the western and central parts of Limfjorden. These locations were also sampled by Bio/consult (2001) and correspond to Locations $B$ and $J$ in the present study. Blanner (1982) presented quantitative data on abundance of the most abundant jellyfish species (>0.1 ind. $\mathrm{m}^{-3}$ ). In all investigations Rathkea octopunctata was the most numerous jellyfish (Table 5). Thirty years ago this species was found in higher concentrations than in the later studies. It has been discussed whether jellyfish occurrence is increasing globally (Mills 2001). With only few historical records no confident statements about the long-term development of jellyfish in Limfjorden can be made. However, based only on the 3 existing studies, there is no indication that medusae in Limfjorden have increased in abundance over the past $30 \mathrm{yr}$, and actually the density of medusae was highest in 1974, but one should bear in mind that abundance can differ by more than one order of magnitude between consecutive years (Bio/consult 2001). The present study illustrates the severe lack of historical data on jellyfish densities and the need for quantitative jellyfish monitoring.

The area investigated appears to be more suitable for jellyfish than the open sea, as density was always lower at the border to the North Sea than in the central parts of Limfjorden. The density of Aurelia aurita in Limfjorden was elevated compared to reports from nearby open sea areas (Hernroth \& Gröndahl 1985, Schneider 1989, Hay et al. 1990) but lower than the extremely high densities of small medusae observed in the small semi-enclosed area Kertinge Nor (Olesen et al. 1994, Riisgård et al. 1996). Jellyfish in Limfjorden comprised a high fraction of the carbon incorporated into zooplankton. From mesozooplankton measurements made by the local county authorities at Locations B, J and M, combined with the present jellyfish abundance and size data, and using the size to carbon relationship described by Larson (1986), it can 
Table 3. Estimated jellyfish-induced half-life times $\left(t_{1 / 2}, \mathrm{~d}\right)$ on copepodites at 12 locations in Limfjorden in 2003. Calculations for August are based solely on predation caused by Aurelia aurita because densities of hydromedusae were not measured. nd $=$ no data collected. $t_{1 / 2}>1 \mathrm{yr}$ are indicated by $\infty$. Average for Limfjorden proper was calculated from all sampled locations except the border location A

\begin{tabular}{|lccccc|}
\hline \multirow{2}{*}{ Location } & \multicolumn{5}{c}{ Copepod half-life times $\left(t_{1 / 2}, \mathrm{~d}\right)$} \\
& February & April & May & July & August \\
\hline A & $\infty$ & 294 & $\infty$ & $\infty$ & nd \\
B & $\infty$ & 80 & $\infty$ & 219 & $\infty$ \\
C & $\infty$ & 29 & 246 & 275 & nd \\
DEF & $\infty$ & $\infty$ & 71 & $\infty$ & nd \\
G & $\infty$ & 144 & $\infty$ & 28 & nd \\
H & $\infty$ & 69 & $\infty$ & $\infty$ & 117 \\
I & 355 & 134 & 38 & 55 & $\infty$ \\
J & $\infty$ & 86 & 57 & 196 & 156 \\
K & 220 & $\infty$ & 49 & 8.0 & nd \\
L & $\infty$ & 109 & 18 & 48 & 65 \\
M & nd & $\infty$ & 21 & 53 & 14 \\
N & nd & $\infty$ & 190 & 87 & 69 \\
Average & $\infty$ & 256 & $\infty$ & 221 & $\infty$ \\
Limfjorden & & & & & \\
& & & & & \\
\hline
\end{tabular}

be estimated that $A$. aurita constituted 51, 44 and $44 \%$ of the total carbon incorporated in zooplankton and jellyfish in May, July and August 2003, respectively. At Location $M$, as much as $85 \%$ of the zooplankton carbon was, averaged over May to August, attributable to A. aurita.

\section{Jellyfish clearance rates}

For Rathkea octopunctata, there are gut content data from other places that enable comparison with Limfjorden data. Reports from a Norwegian fjord (Pagès et al. 1996) and from a Barents Sea fjord (Zelickman et al. 1969) showed that respectively $15.2 \%$ and 1.5 to $17.5 \%$ of the $R$. octopunctata individuals contained food in the gut. Expected fraction of $R$. octopunctata medusae in Limfjorden with one copepod in their guts can be calculated by multiplying clearance rate by a digestion time of $2.3 \mathrm{~h}$ (Matsakis \& Conover 1991) and average concentration of copepods (1.3 ind. $\mathrm{l}^{-1}$ in February and 12 ind. $\mathrm{l}^{-1}$ in April). We would then expect to find $1.25 \%$ of $R$. octopunctata containing a copepod in their gut in February and $11.5 \%$ in April, which is similar to the aforementioned findings from Norway and the Barents Sea. On the other hand, Matsakis \& Conover (1991) measured jellyfish gut contents, digestion times and prey concentration in Bedford Basin, Canada. Based on these data, clearance rates in Bedford Basin can be estimated to ca. 8 and 51 ind..$^{-1} \mathrm{~d}^{-1}$ for adult and juvenile $R$. octopunctata, respectively, feed- ing on copepods, whereas clearance rates in the present study were estimated to ca. 0.11 ind. ${ }^{-1} \mathrm{~d}^{-1}$. The cause of the huge discrepancy in clearance rates between Bedford Basin and the present experimentally derived estimates remains unknown.

Daan (1986) investigated food intake by Sarsia tubulosa and found a linear increase in prey consumption with medusa height. According to that study, a medusa of the height used in the present study would, at constant prey concentrations of 50 copepods $\mathrm{l}^{-1}$, clear ca. $0.5 \mathrm{l} \mathrm{d}^{-1}$. This estimate is slightly higher than the $0.3 \mathrm{l}$ $\mathrm{d}^{-1}$ estimated in the present study, but within 1 standard deviation.

Clearance rates of Aurelia aurita varied widely between prey species (Fig. 9). It is striking that the clearance rate was highest on nauplii of Artemia sp. This prey type is commonly used in laboratory feeding experiments with jellyfish, but the predation rate on Artemia nauplii appears not to be typical of many naturally occurring prey. Caution is therefore required when results from experimental studies with Artemia prey are extrapolated to field conditions.

Table 4. Estimated half-life times $\left(t_{1 / 2}, \mathrm{~d}\right)$ as a consequence of predation by Aurelia aurita on prey cleared at the same rate as cirripede larvae (top) and as Artemia sp. (bottom) at 12 locations in Limfjorden in 2003. nd $=$ no data collected. $t_{1 / 2}>$ $1 \mathrm{yr}$ are indicated by $\infty$. Average for Limfjorden proper was calculated by excluding the border location A

\begin{tabular}{|c|c|c|c|c|c|}
\hline \multirow[t]{2}{*}{ Location } & \multicolumn{5}{|c|}{ Zooplankton half-life times $\left(t_{1 / 2}, \mathrm{~d}\right)$} \\
\hline & February & April & May & July & August \\
\hline \multirow[t]{2}{*}{ A } & $\infty$ & $\infty$ & $\infty$ & $\infty$ & nd \\
\hline & $\infty$ & $\infty$ & $\infty$ & 153 & \\
\hline \multirow[t]{2}{*}{ B } & $\infty$ & $\infty$ & $\infty$ & 7.5 & 82 \\
\hline & $\infty$ & $\infty$ & 283 & 2.8 & 30 \\
\hline \multirow[t]{2}{*}{$\mathrm{C}$} & $\infty$ & 340 & 9.2 & 8.5 & nd \\
\hline & 273 & 79 & 3.2 & 3.3 & \\
\hline \multirow[t]{2}{*}{ DEF } & $\infty$ & $\infty$ & 2.5 & 27 & nd \\
\hline & $\infty$ & 151 & 0.9 & 10 & \\
\hline \multirow[t]{2}{*}{ G } & $\infty$ & $\infty$ & 22 & 1.0 & nd \\
\hline & $\infty$ & 128 & 7.7 & 0.3 & \\
\hline \multirow[t]{2}{*}{$\mathrm{H}$} & $\infty$ & 343 & 126 & 20 & 4.2 \\
\hline & $\infty$ & 80 & 44 & 7.9 & 1.5 \\
\hline \multirow[t]{2}{*}{ I } & $\infty$ & $\infty$ & 1.4 & 1.9 & 108 \\
\hline & $\infty$ & 287 & 0.5 & 0.7 & 37 \\
\hline \multirow[t]{2}{*}{$\mathrm{J}$} & $\infty$ & $\infty$ & 2.1 & 6.7 & 5.6 \\
\hline & $\infty$ & 100 & 0.7 & 2.4 & 2.0 \\
\hline \multirow[t]{2}{*}{$\mathrm{K}$} & $\infty$ & $\infty$ & 1.8 & 0.3 & nd \\
\hline & $\infty$ & $\infty$ & 0.6 & 0.1 & \\
\hline \multirow[t]{2}{*}{$\mathrm{L}$} & $\infty$ & 247 & 0.7 & 1.7 & 2.3 \\
\hline & $\infty$ & 58 & 0.2 & 0.6 & 0.8 \\
\hline \multirow[t]{2}{*}{ M } & nd & 51 & 0.9 & 1.8 & 0.5 \\
\hline & & 12 & 0.3 & 0.7 & 0.2 \\
\hline \multirow[t]{2}{*}{$\mathrm{N}$} & nd & 52 & 8.2 & 3.0 & 2.3 \\
\hline & & 12 & 2.6 & 1.1 & 0.9 \\
\hline Average & $\infty$ & $\infty$ & 91 & 7 & 29 \\
\hline Limfjorden & $\infty$ & 168 & 31 & 3 & 10 \\
\hline
\end{tabular}


Approximate average lengths of prey captured by Aurelia aurita were, in order of decreasing clearance efficiency, Artemia nauplii $700 \mu \mathrm{m}_{\text {; }}$ cirripede larvae

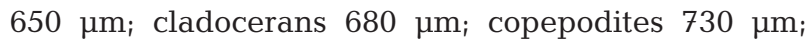
copepod nauplii $250 \mu \mathrm{m}$; and bivalve larvae $150 \mu \mathrm{m}$. Prey longer than $600 \mu \mathrm{m}$ were captured at much higher efficiency than the smaller prey types. However, within the large-prey group, clearance efficiency appears not to be a simple function of prey length. It is not known what governs the selectivity for certain prey, but some insight might be gained by considering the various process of feeding: encounter, contact, capture and ingestion.

The probability of an encounter between 2 particles, such as a prey and a predator with surrounding flow field, increases with their sizes and cruising velocities (Gerritsen \& Strickler 1977). Because the size difference between Aurelia aurita and its prey already is so great, the influence of increased prey size would only make a minute difference to the encounter probability. Furthermore, the prey that were cleared at the highest rates were Artemia nauplii and barnacle nauplii, both of which swim at low velocities. Thus, selectivity for large prey is more likely an effect of postencounter processes.

Prey body shapes and escape capabilities are likely to modify the rate of contact between a prey organism and the prey-capturing sites of the medusa (Costello \& Colin 1994). Nauplii of both Artemia and cirripedes, i.e. the prey groups captured with highest efficiency, are rather bulky with extended appendages and they lack obvious escape responses, whereas copepodites can respond to hydrodynamic signals with pronounced escape behaviors (Kiørboe et al. 1999). This could possibly explain why copepodites were captured at lower efficiency than the other large prey organisms. The big difference in capture efficiency between large prey and small prey may be related to the feeding apparatus of Aurelia aurita, where the probability of passing through the curtain of fringing tentacles is likely to decrease with increasing prey size. Furthermore, for prey of similar density, exceeding that of the fluid, inertia increases with body size. Since a high inertia can make trajectories of large prey deviate from flow fields around the medusa (Shimeta \& Jumars 1991), they might be more likely to come into contact with predator capture sites such as fringing tentacles or oral arms.

Capture efficiency is determined by the ease with which a prey triggers nematocyst release, how efficiently a prey is retained by the nematocysts and to what degree a prey is affected by nematocyst toxins. With today's limited knowledge of Aurelia aurita nematocyst function, these prey-specific factors cannot be predicted. Postcapture selectivity in A. aurita is not
Table 5. Reported maximum densities (ind. $\mathrm{m}^{-3}$ ) of jellyfish in Limfjorden during spring. Data from 1974 (Blanner 1982), 1999 (Bio/consult 2001) and the present study (2003). For each investigation the density values at Locations B (Nissum Bredning) and J (Løgstør Bredning) are indicated. Note: data from 1974 (Blanner 1982) do not include densities < 0.1 ind. $\mathrm{m}^{-3}$

\begin{tabular}{|lccccccc|}
\hline & \multicolumn{2}{c}{1974} & \multicolumn{2}{c}{1999} & \multicolumn{2}{c|}{2003} \\
Species & B & $\mathrm{J}$ & $\mathrm{B}$ & $\mathrm{J}$ & $\mathrm{B}$ & $\mathrm{J}$ \\
\hline Rathkea octopunctata & 427 & 976 & 8.3 & & 86 & 69 \\
Obelia sp. & 244 & 305 & 0.5 & 0.1 & 42 & 16 \\
Aurelia aurita & 7 & 61 & 0.4 & 1.6 & 0.3 & 1.3 \\
Tiaropsis multicirrata & & 7 & & & 0.4 & 7.6 \\
Sarsia sp. & 5 & & 0.2 & 0.6 & 5.8 & 8.3 \\
Cyanea sp. & 1 & & & & 0.04 & \\
Hybocodon prolifer & & & & & 0.3 & 9.4 \\
Bougainvillea sp. & & & & & & 0.06 \\
& & & & & & & \\
\end{tabular}

well known. Southward (1955) described a potential mechanism for rejection of inert particles from the lateral tract of the oral arms, but it is not known whether this applies to the selectivity of certain prey.

Viewed from an ecosystem perspective, selectivity by Aurelia aurita for large prey has some consequences for our understanding of ecosystem function. Greve \& Parsons (1977) suggested that energy may be transferred along 1 of 2 major pathways, either from nanophytoplankton via small zooplankton to gelatinous zooplankton or from microphytoplankton via large zooplankton to young fish. A. aurita clearly does not fit into this model but appears preferably to consume large zooplankton, and the assumption of gelatinous zooplankton eating small prey is not supported for this common predator.

\section{Assumptions}

Like all studies that extrapolate empirical laboratory results to processes at the ecosystem level, this study rests on several assumptions. Laboratory clearance rate measurements with monospecific diets were, for example, assumed to yield clearance rate values comparable to a field situation where the medusae experience a mix of prey species. The effect of a mixed prey assemblage could theoretically be that 1 prey species reacts to the presence of another species with an altered swim behavior, which may lead to a modified encounter rate with the predator. At low prey densities, this effect has most likely only a minor effect on clearance rates. One prey species could also disturb the postencounter handling process of another prey species. Cruising, filtering jellyfish (at least Aurelia aurita) are not food saturated at normal prey concentrations and are thus capable of handling large 
amounts of prey without interference from other species. Ambush feeding hydromedusae could possibly experience reduced clearance rates as a result of 1 species interfering with the handling process. However, with our present knowledge we believe that the clearance rate estimates based on monospecific diets yield an adequate first approximation of potential jellyfish impact.

Clearance rates of several jellyfish species occurring at low density in Limfjorden were not measured directly. However, because abundance of these species was so low, the clearance rate values that were assumed for these species were of minor importance for overall predation impact, as illustrated by the sensitivity analysis (Fig. 10).

Several assumptions are required to estimate clearance rate from gut contents of field-collected medusae, as was done for Aurelia aurita. Medusae were assumed not to take up or lose food during collection and preservation. Because of the sampling techniques used, medusae in this study were not exposed to high plankton concentrations. Furthermore, because medusae were preserved within 2 min after collection, and internal transport of captured prey is a process several times longer than 2 min (Hansson in press), prey concentration in the gut was most likely not elevated due to handling. Physically disturbed A. aurita can lose mucus from the oral arms while prey attached to the gastric filaments appear to be firmly attached. As only prey within the gastric pouches were counted and mucus strings were preserved within the gastric tract, the assumption of no prey loss was probably not violated.

Digestion times were assumed to vary with temperature and prey species. Fig. 2 illustrates the high variability between different measurements of digestion time. Even though the slope of the fitted regression line is not significant, this data fit was used to estimate

Table 6. Coefficient of variation $(\mathrm{CV}, \%)$ calculated from plankton concentrations at (1) all sampled locations in Limfjorden and (2) only those locations that were sampled for gut content analysis and their nearest neighbor locations. nd: no data collected

\begin{tabular}{|c|c|c|c|c|c|}
\hline & $\begin{array}{l}\text { Cirripede } \\
\text { nauplii }\end{array}$ & Cladocera & Copepods & $\begin{array}{c}\text { Copepod } \\
\text { nauplii }\end{array}$ & $\begin{array}{l}\text { Bivalve } \\
\text { larvae }\end{array}$ \\
\hline \multicolumn{6}{|c|}{ (1) Total CV for all Limfjorden locations } \\
\hline February & cy 84 & 157 & 70 & 89 & 119 \\
\hline April & 55 & 142 & 87 & 93 & 269 \\
\hline May & 206 & 220 & 44 & 114 & 115 \\
\hline July & 103 & 93 & 80 & 73 & 223 \\
\hline \multicolumn{6}{|c|}{ (2) Average CV for nearest neighbor locations } \\
\hline April & 15 & nd & 29 & 47 & nd \\
\hline May & 30 & 71 & 43 & 73 & 67 \\
\hline July & 53 & 76 & 22 & 88 & 118 \\
\hline
\end{tabular}

digestion time because activity of the digestive enzymes is likely to increase with temperature, and a trend showing decreasing digestion time with temperature has been shown for gelatinous plankton (Martinussen \& Båmstedt 2001). Most importantly, however, is that the value of digestion time used is of relatively little importance for the results. The temperaturerelated difference in digestion time between April, when the smallest medusae were collected, and July, when the largest medusae were collected, was only 0.8 times. This is negligible compared to the difference in clearance rates between the smallest and largest medusae, which typically is ca. 2 orders of magnitude (Fig. 9). A similar argument can be applied to the literature-based adjustments of digestion time for different prey: a small inaccuracy in digestion time only adds a small error to the very large interspecific difference in the estimated clearance rate of most prey species. However, for copepod nauplii and bivalve larvae the interspecific difference in clearance rate is small and the applied species-specific corrections of digestion time can have an effect on the order of their relative clearance potential (Fig. 9).

Finally, it was assumed that the jellyfish have been feeding at a prey concentration that can be described from the zooplankton samples. This is not true if prey organisms are patchily distributed on such a scale that medusae have moved from 1 prey concentration to another during the time from ingestion to collection. Plankton patchiness on a horizontal scale is only known between locations. Average distance between neighboring locations was 19 (SD 6) km, which is ca. 100 times the distance that a large medusa can move during the time it takes to digest 1 prey (Hansson 2005). Furthermore, the horizontal variation was usually moderate between neighboring locations (Table 6). Vertical stratification can produce vertical heterogeneity in jellyfish abundance, but during the cruises in 2003 the shallow water in Limfjorden appeared vertically homogenous and no marked pycnocline could be detected at any location. The largest density difference between surface and bottom of the water column was only $\Delta \sigma_{t}=2.6$. Unless the medusae move systematically relative to a prey concentration gradient, the effect of patchiness will only be to increase the scatter in the data (Fig. 9). Thus, clearance rates estimated from the gut contents of Aurelia aurita appear relatively robust to the underlying assumptions.

\section{Impact on zooplankton}

The calculated jellyfish-induced half-life times of copepodites in Limfjorden were not shorter than $29 \mathrm{~d}$ in February and early April (Table 3), indicating the low 
importance of jellyfish predation during this time. The general impact of hydromedusa feeding thus appears to be of minor importance for copepods. However, the effect of Aurelia aurita predation from May onwards is locally of such magnitude that it most likely will affect some zooplankton populations (Tables $3 \& 4$ ). The mean half-life time of cirripede larvae in May was typically on the scale of some hours to a few days. This is considerably shorter than the time that these meroplankters spend as larvae in the water column, which is on the order of several weeks. Thus, A. aurita probably controls the amount of balanoid larvae from April/May onwards. This control may well be a local phenomenon characteristic of Limfjorden, as half-life times in Location A, which is expected to be heavily affected by the North Sea, were much longer. It is likely that also other organisms experience severe population reductions by predation from A. aurita. Mortality rates on copepodites for example were several percent per day, especially in the eastern and southeastern parts of Limfjorden (Fig. 11). This constitutes a relatively large fraction of total copepod mortality rate, which typically is approximately $0.1 \mathrm{~d}^{-1}$ at those temperatures (Hirst \& Kiørboe 2002). Estimated half-life times for copepodites were locally much shorter than expected generation times for calanoid copepods (Table 3). The suggested jellyfishinduced control of prey populations is supported by field observations showing that abundance of both cirripede larvae and copepods were lower in locations with high estimated predation impact than in locations where this was low (Fig. 12). Mean prey abundance declined hyperbolically with estimated mortality rate.

Jellyfish impact on fish recruitment can be assessed from jellyfish clearance rates and the time that fish eggs and larvae were exposed to the predators. Egg-hatching times at ambient temperatures are ca. 6 and $4 \mathrm{~d}$ for sole in May and July respectively and $11 \mathrm{~d}$ for plaice in May (Thompson \& Riley 1981). Clearance rates on fish eggs are not known for most medusae. However, because both of the dominating spring species Rathkea octopunctata and Sarsia sp. are mainly raptorial feeders, relying on prey motility for encounter, the predation by these medusae on the non-motile fish eggs would expectedly be of little importance. However, Matsakis \& Conover (1991) found that in Bedford Basin eggs $>200 \mu \mathrm{m}$ made up $40 \%$ of the prey found in the guts of $R$. octopunctata, and copepods constituted $52 \%$ of the gut contents. Sarsia princeps, on the other hand, only consumed copepods. Prey selectivity by medusae in Bedford Basin can be calculated from reported data on prey concentrations in ambient water and medusa gut contents, assuming equal digestion times for copepods and eggs as demonstrated for Aglantha digitale (Matsakis \& Conover 1991). Prey selectivity for eggs over copepods ranged from negative selectivity up to 5

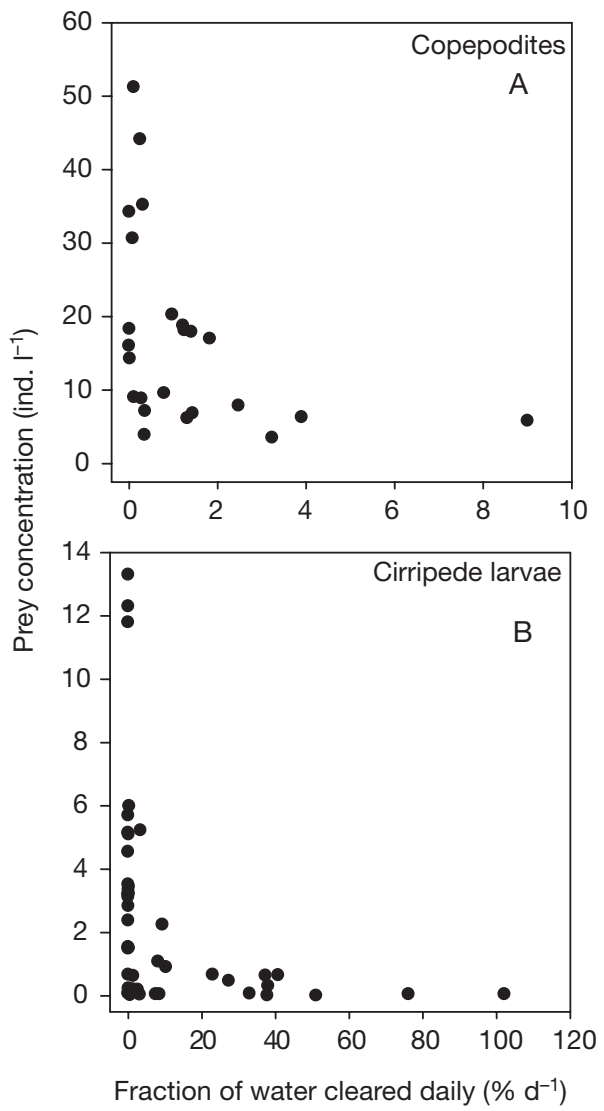

Fig. 12. Daily jellyfish induced potential mortality $\left(\% \mathrm{~d}^{-1}\right)$ at different locations and times in Limfjorden plotted against prey density. (A) Potential mortality on copepodites due to predation by the total jellyfish community. (B) Potential mortality on cirripede larvae due to predation by Aurelia aurita. Data from 2 sampling occasions with extremely dense patches of $A$. aurita have been omitted from (B)

times higher affinity for eggs than copepods. An extreme situation for Limfjorden would be Location $\mathrm{C}$ in April ( $t_{1 / 2}=29 \mathrm{~d}$, Table 3$)$ with a selectivity 5 times higher for fish eggs than for copepods. In this situation, expected half-life time would be $6 \mathrm{~d}$, thus more than halving the standing stock of any eggs with a development time longer than $6 \mathrm{~d}$. However, in most locations jellyfish would consume much less than half of the pelagic eggs in spring. Clearance rate by Aurelia aurita on fish eggs has not been established, but prey selectivity studies could potentially indicate how efficient this jellyfish is in capturing fish eggs compared to other prey. However, Graham \& Kroutil (2001) did not find any clear positive or negative selectivity for fish eggs compared to small and large copepods.

The size-specific clearance rate of Aurelia aurita on early stage yolk sac cod larvae is intermediate between that for cirripede larvae and Artemia nauplii (J. Titelman \& L. J. Hansson unpubl. data), implying that A. aurita causes a high mortality rate among fish larvae in 
Limfjorden. This high mortality risk probably diminishes as the fish grow because predation efficiency for several fish species rapidly declines as fish larvae develop (Bailey \& Batty 1984). In July there was a high abundance of fish larvae developed from pelagic eggs. However, mean length of the sprat larvae at this time was only $7.5 \mathrm{~mm}$ and those of sole $3.7 \mathrm{~mm}$, suggesting that most of these larvae may in fact be consumed by A. aurita.

\section{Secondary effects of jellyfish predation}

Competition for prey between planktivorous fish and jellyfish has sometimes been suggested. Purcell \& Arai (2001) pointed out that this is difficult to prove because prey competition requires a substantial overlap in potential diet and a shortage of food and that prey populations are limited by predation. Concentrations of zooplankton that could potentially be used as prey for planktivorous fish (copepod nauplii, early copepodite stages, bivalve veligers) were lower in Limfjorden than in the open sea, but far from extremely low. Thus, the data do not immediately suggest a general prey competition between fish larvae and jellyfish in the area.

Lindahl \& Hernroth (1983) suggested that high jellyfish predation on grazers of phytoplankton allowed algal populations in Gullmarsfjorden, Sweden to grow in the summer. The purpose of the present study was not to collect data to detect such trophic cascade effects. However, it is noteworthy that the extraordinarily high mortality rates on copepods at Location M in August (Table 3) coincided with the highest chlorophyll a concentrations recorded in Limfjorden in $2003\left(40 \mathrm{~g} \mathrm{l}^{-1}\right.$ reported by local county authorities), suggesting that jellyfish-induced mortality on phytoplankton grazers could have contributed to a local algal bloom.

Acknowledgements. We thank J. Knudsen, O. Madvig Larsen, G. Pedersen, J. Lomborg and Limfjordsamterne for valuable field assistance. This work formed part of the EUROGEL project (EVK3-CT-2002-00074) supported by the European Commission.

\section{LITERATURE CITED}

Bailey KM, Batty RS (1984) Laboratory study of predation by Aurelia aurita on larvae of cod, flounder, plaice and herring: development and vulnerability to capture. Mar Biol 83:287-291

Baird D, Ulanowicz RE (1989) The seasonal dynamics of the Chesapeake Bay ecosystem. Ecol Monogr 59:329-364

Behrends G, Schneider G (1995) Impact of Aurelia aurita medusae (Cnidaria, Scyphozoa) on the standing stock and community composition of mesozooplankton in the Kiel Bight (western Baltic sea). Mar Ecol Prog Ser 127:39-45

Bio/consult (2001) Fiskelarver og gopler i Limfjorden, foråret
1996-1999. Report in Danish produced for Limfjordssamarbejdet, v/Nordjyllands Amt, Ålborg, Denmark

Blanner P (1982) Composition and seasonal variation of the zooplankton in the Limfjord (Denmark) during 1973-1974. Ophelia 21:1-40

Brodeur R, Sugisaki H, Hunt Jr G (2002) Increases in jellyfish biomass in the Bering Sea: implications for the ecosystem. Mar Ecol Prog Ser 233:89-103

Båmstedt U, Martinussen MB (2000) Estimating digestion rate and the problem of individual variability, exemplified by a scyphozoan jellyfish. J Exp Mar Biol Ecol 2511:1-15

Båmstedt U, Martinussen MB, Matsakis S (1994) Trophodynamics of the two scyphozoan jellyfishes, Aurelia aurita and Cyanea capillata, in western Norway. ICES J Mar Sci 51:369-382

Båmstedt U, Wild B, Martinussen M (2001) Significance of food type for growth of ephyrae Aurelia aurita (Scyphozoa). Mar Biol 139:641-650

Costello JH, Colin SP (1994) Morphology, fluid motion and predation by the scyphomedusa Aurelia aurita. Mar Biol 121:327-334

Daan R (1986) Food intake and growth of Sarsi tubulosa (Sars, 1835), with quantitative estimates of predation on copepod populations. Neth J Sea Res 20:67-74

Dawson M, Martin L (2001) Geographic variation and ecological adaptation in Aurelia (Scyphozoa, Semaeostomeae): some implications from molecular phylogenetics. Hydrobiologia 451:259-273

de Lafontaine Y, Leggett W (1988) Predation by jellyfish on larval fish: an experimental evaluation employing in situ enclosures. Can J Fish Aquat Sci 45:1173-1190

Dolmer P, Frandsen RP (2002) Evaluation of the Danish mussel fishery: suggestions for an ecosystem management approach. Helgol Mar Res 56:13-20

Duffy J, Epifanio C, Fuiman L (1997) Mortality rates imposed by three scyphozoans on red drum (Sciaenops ocellatus Linnaeus) larvae in field enclosures. J Exp Mar Biol Ecol 212:123-131

Fancett M, Jenkins G (1988) Predatory impact of scyphomedusae on ichthyoplankton and other zooplankton in Port Phillip Bay. J Exp Mar Biol Ecol 116:63-77

Feigenbaum D, Kelly M (1984) Changes in the lower Chesapeake Bay food chain in presence of the sea nettle Chrysaora quinquecirrha (Scyphomedusa). Mar Ecol Prog Ser 19:39-47

Fulton R, Wear R (1985) Predatory feeding of the hydromedusae Obelia geniculata and Phialella quadrata. Mar Biol $87: 47-54$

Gerritsen J, Strickler JR (1977) Encounter probabilities and community structure in zooplankton: a mathematical model. J Fish Res Board Can 34:73-82

Graham WM, Kroutil RM (2001) Size-based prey selectivity and dietary shifts in the jellyfish, Aurelia aurita. J plankton Res 23:67-74

Greve W, Parsons TR (1977) Photosynthesis and fish production: Hypothetical effects of climatic change and pollution. Helgol Wiss Meeresunters 30:666-672

Hansen LJ (2005) A method for in situ estimation of prey selectivity and predation rate in large plankton, exemplified with the jellyfish Aurelia aurita. J Exp Mar Biol Ecol (in press)

Hay SJ, Hislop JRG, Shanks AM (1990) North Sea scyphomedusae; summer distribution, estimated biomass and significance particularly for 0-group gadoid fish. Neth J Sea Res 25:113-130

Hernroth L, Gröndahl F (1985) On the biology of Aurelia aurita (L.):2. Major factors regulating the occurrence of 
ephyrae and young medusae in the Gullmar Fjord, western Sweden. Bull Mar Sci 37:567-576

Hirst A, Kiørboe T (2002) Mortality of marine planktonic copepods: global rates and patterns. Mar Ecol Prog Ser 230:195-209

Huntley ME, Hobson LA (1978) Medusa predation and plankton dynamics in a temperate fjord, British Columbia. J Fish Res Board Can 35:257-261

Ishii H, Tanaka F (2001) Food and feeding of Aurelia aurita in Tokyo Bay with an analysis of stomach contents and a measurement of digestion times. Hydrobiologia 451: $311-320$

Jørgensen BB(1980) Seasonal oxygen depletion in the bottom waters of a Danish fjord and its effect on the benthic community. Oikos 34:68-76

Kiørboe T, Saiz E, Visser A (1999) Hydrodynamic signal perception in the copepod Acartia tonsa. Mar Ecol Prog Ser 179:97-111

Kopacz U (1994) Evidence for tidally-induced vertical migration of some gelatinous zooplankton in the Wadden Sea area near Sylt. Helgol Meeresunters 48:333-342

Larson RJ (1986) Water content, organic content, and carbon and nitrogen composition of medusae from the northeast Pacific. J Exp Mar Biol Ecol 99:107-120

Larson RJ (1991) Diet, prey selection and daily ration of Stomolophus meleagris, a filter-feeding scyphomedusa from the NE Gulf of Mexico. Estuar Coast Shelf Sci 32:511-525

Lindahl O, Hernroth L (1983) Phyto-zooplankton community in coastal waters of western Sweden - an ecosystem off balance? Mar Ecol Prog Ser 10:119-126

Martinussen M, Båmstedt U (1999) Nutritional ecology of gelatinous planktonic predators. Digestion rate in relation to type and amount of prey. J Exp Mar Biol Ecol 232:61-84

Martinussen M, Båmstedt U (2001) Digestion rate in relation to temperature of two gelatinous planktonic predators. Sarsia 86:21-35

Matsakis S, Conover RJ (1991) Abundance and feeding of medusae and their potential impact as predators on other zooplankton in Bedford Basin (Nova Scotia, Canada) during spring. Can J Fish Aquat Sci 48:1419-1430

Mills C (2001) Jellyfish blooms: are populations increasing globally in response to changing ocean conditions? Hydrobiologia 451:55-68

Morand P, Carré C, Biggs DC (1987) Feeding and metabolism of the jellyfish Pelagia noctiluca (scyphomedusae, semaeostomae). J Plankton Res 9:651-665

Möller H (1984) Reduction of a larval herring population by jellyfish predator. Science 224:621-622

Nicholas K, Frid C (1999) Occurrence of hydromedusae in the plankton off Northumberland (western central North Sea) and the role of planktonic predators. J Mar Biol Assoc UK 79:979-992

Nielsen A, Pedersen A, Riisgård HU (1997) Implications of density driven currents for interaction between jellyfish (Aurelia aurita) and zooplankton in a Danish fjord. Sarsia 82:297-305

Olesen NJ, Frandsen K, Riisgård HU (1994) Population dynamics, growth and energetics of jellyfish Aurelia aurita in a shallow fjord. Mar Ecol Prog Ser 105:9-18

Olesen NJ (1995) Clearance potential of jellyfish Aurelia aurita, and predation impact on zooplankton in a shallow cove. Mar Ecol Prog Ser 124:63-72

Olsson P, Graneli E, Carlsson P, Abreu P (1992) Structuring of a postspring phytoplankton community by manipulation of trophic interactions. J Exp Mar Biol Ecol 158:249-266

Pagès F, González HE, González SR (1996) Diet of the gelatinous zooplankton in Hardangerfjord (Norway) and poten- tial predatory impact by Aglantha digitale (Trachymedusae). Mar Ecol Prog Ser 139:69-77

Purcell J (1992) Effects of predation by the scyphomedusan Chrysaora quinquecirrha on zooplankton populations in Chesapeake Bay, USA. Mar Ecol Prog Ser 87:65-76

Purcell J, Arai M (2001) Interactions of pelagic cnidarians and ctenophores with fish: a review. Hydrobiologia 451:27-44

Purcell J, Cowan Jr J (1995) Predation by the scyphomedusan Chrysaora quinquecirrha on Mnemiopsis leidyi ctenophores. Mar Ecol Prog Ser 129:63-70

Purcell J, Grover J (1990) Predation and food limitation as causes of mortality in larval herring at a spawning ground in British Columbia. Mar Ecol Prog Ser 59:55-61

Purcell J, Nemazie D (1992) Quantitative feeding ecology of the hydromedusan Nemopsis bachei in Chesapeake Bay. Mar Biol 113:305-311

Purcell J, White J, Roman M (1994) Predation by gelatinous zooplankton and resource limitation as potential controls of Acartia tonsa copepod populations in Chesapeake Bay. Limnol Oceanogr 39:263-278

Riisgård HU, Christensen PB, Olesen NJ, Petersen JK, Møller MM, Andersen P (1995) Biological structure in a shallow cove (Kertinge Nor, Denmark): control by benthic nutrient fluxes and suspension-feeding ascidians and jellyfish. Ophelia 41:329-344

Riisgård HU, Jürgensen C, Andersen F (1996). Case study: Kertinge Nor. In: Barker Jørgensen B, Richardson K (eds) Eutrophication in coastal marine ecosystems. Coast Estuar Stud 52:205-221

Schneider G (1989) The common jellyfish Aurelia aurita: standing stock, excretion and nutrient regeneration in the Kiel Bight, Western Baltic. Mar Biol 100:507-514

Schneider G (1989) Estimation of food demands of Aurelia aurita medusae populations in the Kiel Bight/western Baltic. Ophelia 31:17-27

Schneider G, Behrends G (1994) Population dynamics and the trophic role of Aurelia aurita medusae in the Kiel Bight and western Baltic. Ices J Mar Sci 51:359-367

Schneider G, Behrends G (1998) Top-down control in a neritic plankton system by Aurelia aurita medusae - a summary. Ophelia 48:71-82

Shimeta J, Jumars PA (1991) Physical mechanisms and rates of particle capture by suspension feeders. Oceanogr Mar Biol Annu Rev 29:191-257

Southward AJ (1955) Observations on the ciliary currents of the jelly-fish Aurelia aurita L. J Mar Biol Assoc UK 34: 201-216

Stibor H, Vadstein O, Diehl S, Gelzleichter A and 11 others (2004) Copepods act as a switch between alternative trophic cascades in marine pelagic food webs. Ecol Lett 7: 321-328

Sullivan BK, Garcia JR, Klein-MacPhee G (1994) Prey selection by the scyphomedusan predator Aurelia aurita. Mar Biol 121:335-341

Thompson B, Riley J (1981) Egg and larval development studies in the North Sea cod (Gadus morhua L.). Rapp P-V Réun Cons Int Explor Mer 178:553-559

van der Veer HW (1985) Impact of coelenterate predation on larval plaice Pleuronectes platessa and flounder Platichthys flesus stock in the western Wadden Sea. Mar Ecol Prog Ser 25:229-238

Zelickman E, Gelfand V, Shifrin M (1969) Growth, reproduction and nutrition of some Barents Sea hydromedusae in natural aggregations. Mar Biol 4:167-173

Øiestad V (1985) Predation on fish larvae as a regulatory force, illustrated in mesocosm studies with large groups of larvae. NAFO Sci Counc Stud 8:25-32 